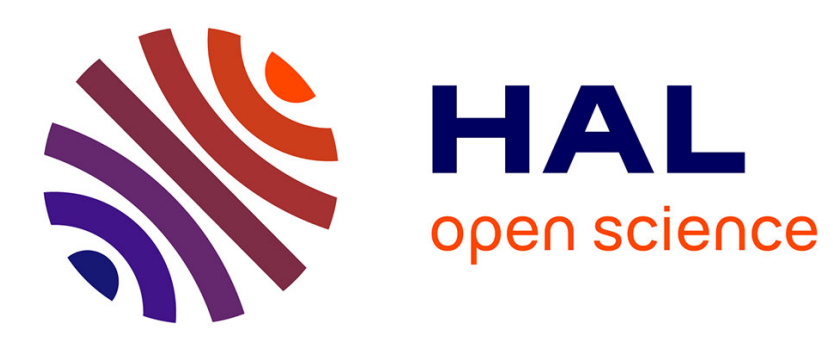

\title{
Latest developments in foodborne pathogen risk assessment
}

\author{
Jeanne Marie J. M. Membré, Sandrine Guillou
}

\section{To cite this version:}

Jeanne Marie J. M. Membré, Sandrine Guillou. Latest developments in foodborne pathogen risk assessment. Current Opinion in Food Science, 2016, 8, pp.120-126. 10.1016/j.cofs.2016.04.011 . hal02635910

\section{HAL Id: hal-02635910 \\ https://hal.inrae.fr/hal-02635910}

Submitted on 27 May 2020

HAL is a multi-disciplinary open access archive for the deposit and dissemination of scientific research documents, whether they are published or not. The documents may come from teaching and research institutions in France or abroad, or from public or private research centers.
L'archive ouverte pluridisciplinaire HAL, est destinée au dépôt et à la diffusion de documents scientifiques de niveau recherche, publiés ou non, émanant des établissements d'enseignement et de recherche français ou étrangers, des laboratoires publics ou privés. 


\section{Latest developments in foodborne pathogen risk assessment Jeanne-Marie Membré ${ }^{1,2}$ and Sandrine Guillou ${ }^{2}$}

\begin{abstract}
Microbiological Risk Assessment (MRA) is a structured process for determining the public health risk associated with foodborne pathogens. In recent years, there has been a strong tendency in providing food safety decisions based upon quantitative assessment. Especially, variability and uncertainty inherent to biological processes have been integrated in food safety management through the use of powerful statistical and probabilistic techniques. Besides, recent developments in omic technologies may fill knowledge gaps on strain diversity and physiological variability, and, open new perspectives to refine hazard identification. Last, to satisfy the societal demand for balanced recommendations on food, MRA could be, in a near future, embedded into a more comprehensive assessment including chemical and nutritional issues, but also, cost and sustainability considerations.
\end{abstract}

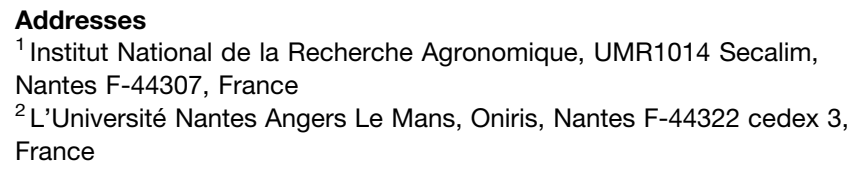

\section{Introduction}

The World Health Organization (WHO) and the Food and Agriculture organization (FAO), particularly through the Codex Alimentarius Commission (CAC) have encouraged the research community (academy, regulatory agencies) to perform Microbiological Risk Assessment (MRA). In 1999, they published a guideline to facilitate the use of MRA [1]. MRA is a structured process for determining the public health risk associated with biological hazard in food. It includes hazard identification, exposure assessment, hazard characterization and risk characterization [1]. Generally, in MRA, the microbial propagation from the primary production up to consumer's plate is taken into account. That enables to suggest and evaluate management options associated with any step of the "farm-to-fork" continuum. In this context, MRA is often quantitative and more precisely probabilistic. Probabilistic refers to the process of characterizing inputs using probability density distributions [2]. That provides the flexibility of comparing the efficiency of different risk reduction measures by predicting their effect on the model output, while taking the variability into account. Concerning the exposure assessment, the probability of having a consumer exposed to a pathogenic hazard depends upon the level of the pathogen in the food and the consumer's habits (Figure 1). The level of pathogen in food is a function of its ability to adapt to multiple process/formulation stresses encountered during the production and distribution chain, but also upon the food matrix and the potential presence of endogenous flora which might limit or, on the opposite, enhance the pathogenic growth. Concerning the hazard characterization, that is evaluation of the nature of the adverse health effects associated with the hazard [1], the probability for a consumer of being ill once exposed depends upon the environmental conditions that the pathogen has undergone before ingestion (in particular during food transformation and distribution), the pathogen virulence and the host susceptibility (Figure 1). Within both exposure assessment and hazard characterization, there are a lot of different sources of variability which have to be taken into account to estimate accurately the risk. Omic technologies (particularly genomics and transcriptomics), whose potential use in food safety have recently been reviewed $\left[3^{\bullet \bullet}, 4\right]$, might help to decipher this variability, while statistical and probabilistic techniques should help in digesting the amount of data and turn it in useful information. The objective of this review is to cover all these aspects by sharing some insights into the current status and future trends in foodborne pathogen risk assessment, from the microbial cell to the societal demand perspective.

\section{Risk-based food safety management}

MRA is interconnected with risk management and risk communication in the risk analysis process. In 2002, WHO and FAO set down the basis of risk-based food safety management [5]. Within this latter framework, a Food Safety Objective (FSO) corresponds to the maximum frequency and/or concentration of a hazard in a food at the time of consumption that provides or contributes to an Appropriate Level of Protection (ALOP) of the population. The Performance Objective (PO) is directly related to the FSO but is set at a step before the time of consumption (e.g. at the point of product release from manufacture) [5]. Operational critical limits (such as 


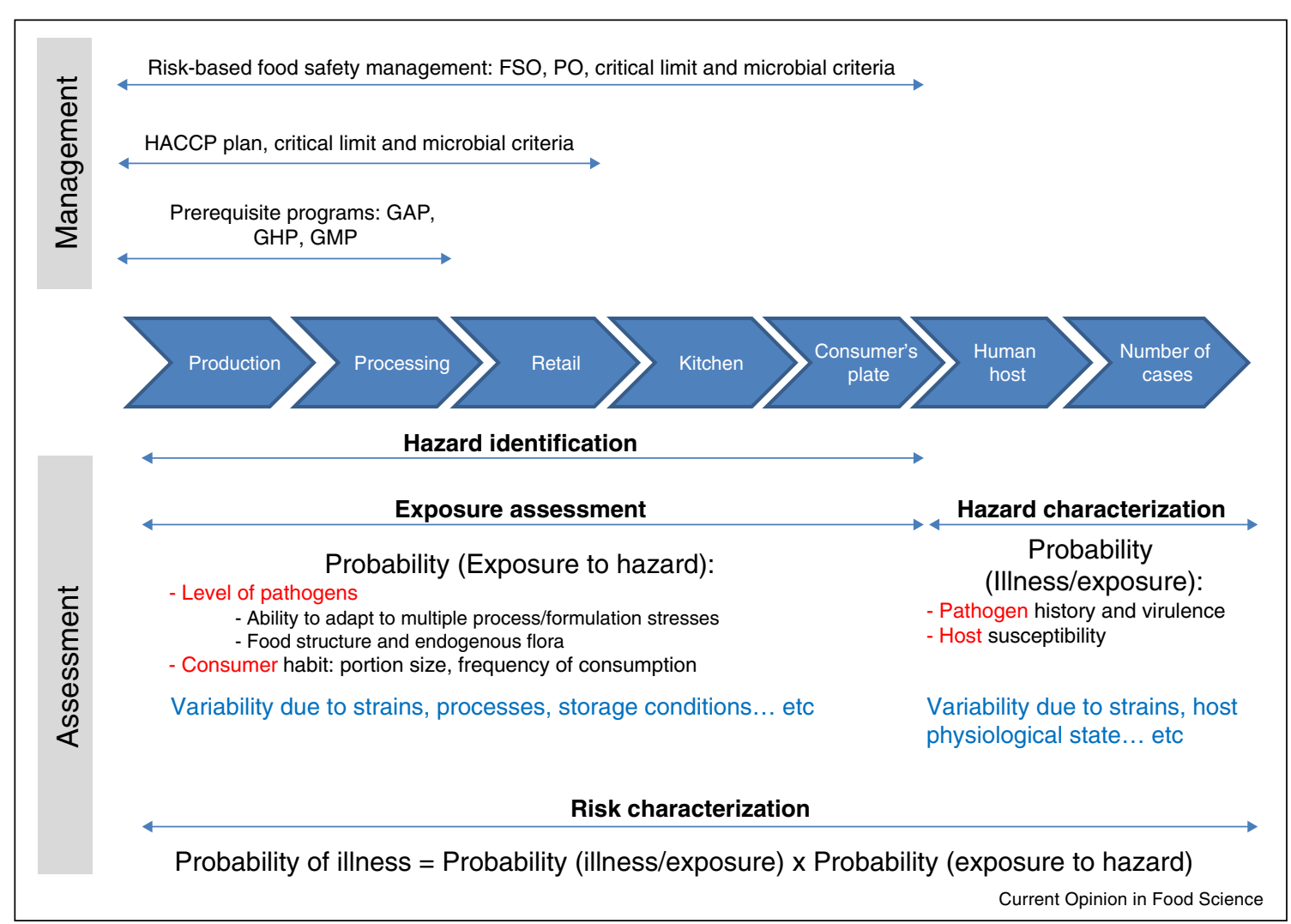

Microbiological Risk Assessment, food safety management: their place in the farm-to-fork-to-human continuum.

Critical Control Points in HACCP) and microbial criteria, are then set to guarantee that process and formulation associated with a given food product comply with $\mathrm{PO}$ and FSO [6-10]. This recently introduced risk-based food safety management comes on top of, but does not replace, prerequisite programmes and HACCP plan (Figure 1).

To have a risk-based food safety management effectively implemented, it is necessary to make a quantitative link between operational settings (e.g. thermal process criteria) and PO or FSO. That is possible using the wellestablished Modular Process Risk Model introduced 15 years ago by Nauta [11]. In this model, the food transformation/distribution operations are divided into smaller steps influencing microbial contamination level (concentration and prevalence), among them: (i) the introduction of microorganisms with the raw materials, (ii) the microbial inactivation (for instance by heat treatment), (iii) the potential post-process recontamination of the product, and (iv) the growth or survival of microorganisms during intermediate or final storage. Quantitative MRA were first of all developed for foodborne bacteria, however nowadays, there are studies focused on development of mathematical models describing the exposure and/or the risk of norovirus and hepatitis A virus associated with food consumption [12-14].

Although food process and formulation are important factors to take into account when assessing the risk and identifying measures to prevent or control this risk, recent MRA studies have pointed out that consumers, by their preferences and behaviours, play a crucial role in the overall risk of foodborne disease. For instance, Daelman et al. [15] have highlighted that time and temperature in consumer refrigerators were the most important variables (top rank in the model including in-factory process and retail distribution steps) impacting the level of Bacillus cereus in cooked chilled products at the moment of consumption. Beside storage, a substantial proportion of foodborne disease has been attributable to improper food preparation practices in consumers' homes [16]. It is also worth mentioning that still nowadays, despite official recommendations, many consumers keep preferring undercooked hamburgers [17]. For all these reasons, it seems reasonable to forecast that research on consumers will continue in the near future: assessment of their role, perception and communication towards them, importance of labelling, social network role, etc. 


\section{Essential place of variability in risk assessment}

Variability refers to real and identifiable differences between individuals within a population addressed by risk assessment. Variability is inherent to any biological process [18] and does not disappear with more data collection. There are a lot of sources of variability along the farm-to-human continuum (Figure 1), which could be split into three groups: those associated with the pathogen, with the food product and with the consumer. Concerning the pathogen, microbial contamination of raw material or factory environment varies between batches and plants while microbial adaptation to stress encountered during food processing/formulation and virulence vary between strains of a given species $[19,20]$ and even among cells from a given strain $\left[21^{\circ}\right]$. Concerning the food product, its characteristics (texture, $\mathrm{pH}, a_{\mathrm{w}}$, etc.) vary between batches, its endogenous flora composition varies, among other, with raw material origin and season. Consumer is also a large source of variability: by his/her behaviour and awareness regarding food safety, and his/her susceptibility to disease as the pathogen host. To decipher better the variability, high-resolution omics-based analyses such as genomics, transcriptomics, proteomics and metabolomics embody a promising toolbox (Figure 2) [22].

\section{Omic technologies may fill knowledge gaps in MRA}

Variability first arises from the diversity of pathogenic agents and sources of contamination, which makes the identification of hazard complicated. One application of omics in MRA concerns the use of Whole Genome Sequencing (WGS) for a more accurate hazard identification. Indeed, the use of WGS in genomic epidemiology of outbreaks caused by a pathogen enables a resolution gain in identification of the bacterial agent with respect to traditional epidemiological tools [23]. Routine use of WGS for surveillance has been implemented in 2013 by the U.S. CDC for all human Listeria monocytogenes isolates [3]. WGS has been also applied for the detection of parasites and viruses but not yet as a routine method

\section{Figure 2}

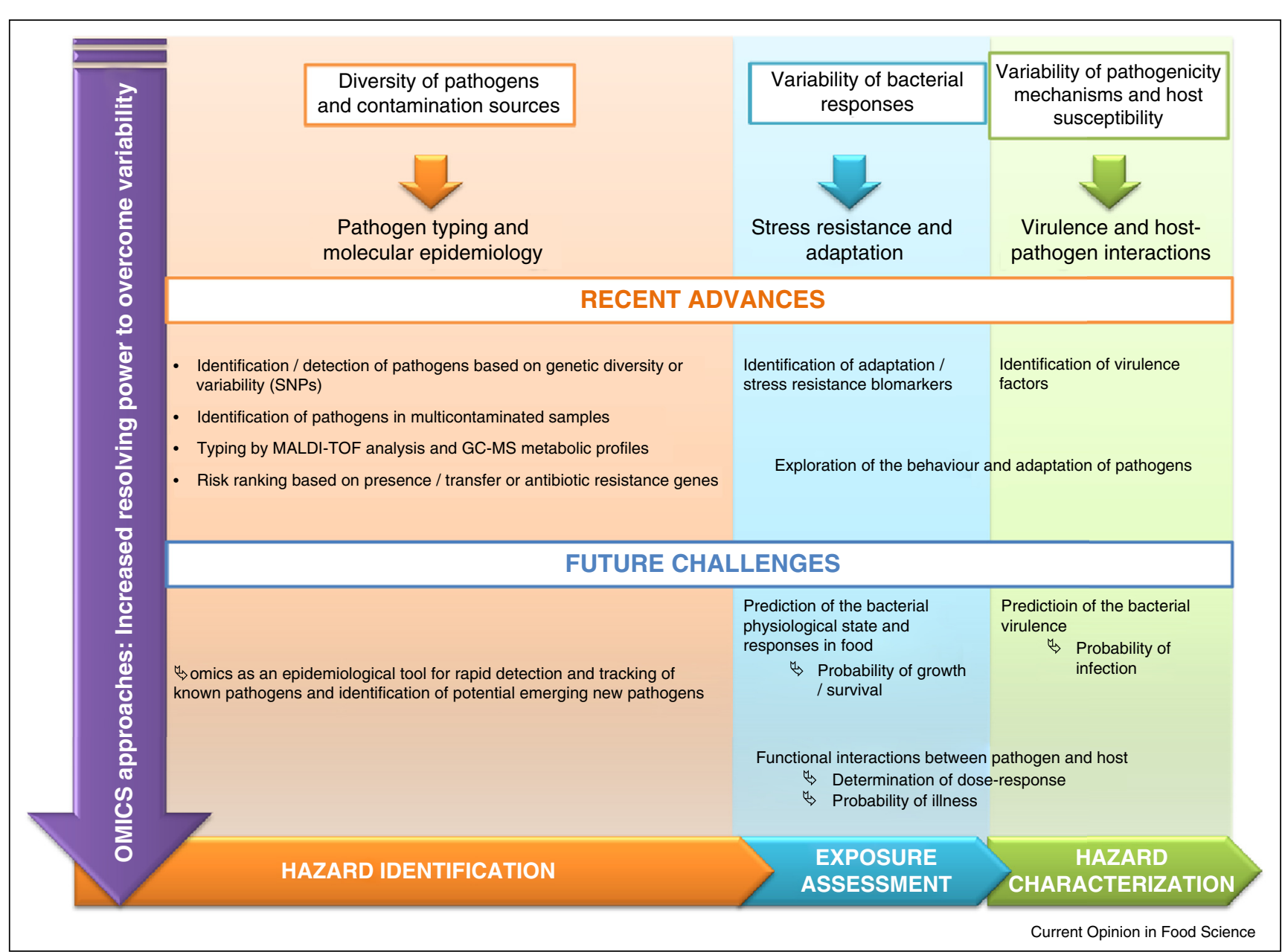

Recent advances and challenges of omics-driven approaches to overcome variability in Microbiological Risk Assessment. 
[3]. Moreover, through analysis of genetic variability, tracking similarities between single-nucleotide polymorphisms (SNPs) among various bacterial isolates provides new insights to identify the sources of contamination $\left[24^{\circ}\right]$ and understand the mechanisms of transmission of infection [25]. The significant advances in Next Generation Sequencing (NGS) technologies also offer the possibility to profile entire microbial communities in complex and contaminated food matrices all along the food chain supply without a priori consideration and without culture bias. However the main obstacle to integration of metagenomics in MRA resides in the relative but not absolute quantification of reads, limiting its application to detection rather than quantification. Shotgun metagenomic sequencing has recently been used to track in spinach multicontaminated samples Shiga toxinproducing Escherichia coli [26]; it might be also used for ranking risk of detection of antibioresistance genes [27]. As well as genomics, metabolomics through gas chromatography-mass spectrometry [28] and MALDI-TOF mass spectrometry techniques [29] can also be used for bacterial identification in the form of specific metabolite or protein fingerprints [4].

On the other hand, the exposure assessment step of MRA needs to integrate the variability of adaptation/stress responses associated with bacterial growth and survival all along the food chain supply. Omic methods could help to progress in this direction. For instance, identification of pathways involved in pathogen stress adaptation patterns has been determined by comparative genome analysis in food [30]. More recently, differential gene expression analysis and genome-wide transcriptome analysis have been used to identify food-related stress resistance biomarkers [31-34].

In hazard characterization, there are a lot of studies aiming at identifying virulence factors in microbial pathogens $[35,36]$. However the potential metabolic capacities of pathogens to adapt to food and host environments would worthy to be investigated [37,38], that might be done by combining different omic strategies altogether as suggested by Yang [39]. On the other hand, Gale et al. [40] explored the possibility of building a dose-response model for RNA virus but they could not succeed in having a quantitative estimation of probability of infection on the basis of omic data. Finally, metabolomics and more specifically fluxomics seems a valuable technique to progress on hazard characterization [41], even if reconstructing causal gene-metabolite network will be always difficult [42].

\section{Statistical and probabilistic techniques to support risk assessment}

To date, generating omic data does not support risk assessment, except maybe for hazard identification. To create added-value information for risk assessment, after the compulsory step of bioinformatics, comes the step of statistical and probabilistic analysis.

Among the statistical techniques, regression is traditionally used. For instance, WGS data have been compared to data of in vitro adherence to epithelial cells (as a proxy for virulence) using a mixed effect regression model in a study on Shiga toxin-producing E. coli $\left[24^{\circ}\right]$. The authors pointed out that the main bottleneck in their approach was the difficulty of translating genotype-level multidimensional information into the single dimension associated with the measure of risk. Partial Least Square Regression (PLSR) is another regression technique used to interpret omic data. PLSR has been carried out to identify biomarkers (i.e. a set of genes whose expression varies with the microbial environment changes) of acidic stress resistance and osmotic and acidic stress resistance for Bacillus weihenstephanensis [32] and L. monocytogenes [31], respectively. Although somewhat black box approach (the specific role of genes in stress response are not well determined), the identification of biomarkers could lead to the quantification of probability of exposure in food.

Beside regression, Bayesian networks and graph theory method are powerful techniques to decipher information from a multidimensional set of data. Bayesian networks have been used to build gene regulatory networks, based on gene knocking-out experiments [43], graph theory method [44] has been carried out by Pin et al. [45] in an attempt of elucidating the molecular mechanisms underlying $E$. coli lag phase, with the objective of predicting its duration.

Bayesian inference might be also a valuable tool to overcome the challenge of lack of biological data (a large set of data does not mean that the right data have been collected). In contrast with "classical" statistics (i.e. frequentist approach), in Bayesian inference, prior knowledge of biologists (food microbiologists, microbial ecologists, food safety assessors, epidemiologists, ...) can be combined with data generated on purpose to estimate more accurately model parameters. Recently, Bayesian inference has been applied to omic data to understand the dynamic of a microbial community structure in human [46].

Not only for analysing omic data but more generally for facing the lack of data inherent to biological phenomena in MRA, the use of Bayesian techniques (Bayesian inference, Bayesian graphical models) is gaining interest $\left[47,48^{\circ}\right]$. They have been used to assess microbial prevalence [49] and contamination level [50], inactivation of pathogens in food [51,52], and more generally in microbial exposure or risk assessment $\left[48^{\bullet}, 53,54\right]$. The lack of data is a source of uncertainty. Uncertainty and variability correspond to two distinct notions. As already mentioned, 
variability represents the natural variation in a population (statistical population: food, process, microorganism, human). Uncertainty refers to a lack of data. In exposure assessment, uncertainty could be associated with a lack of data to characterize the level of raw material contamination, growth rate, gene expression, etc. In hazard characterization, for instance, uncertainty could be associated with a lack of data to characterize the virulence due to the difficulty of generating large sample size with in vivo experiments. Uncertainty arises also from our lack of data when building a model (exposure assessment model and/ or dose-response model), resulting in having not the right model, not the right model parameter estimates, or both. In some cases, we can reduce uncertainty by obtaining better information (more data, better expert elicitation), but this may not always be possible. The current trend in quantitative MRA is to distinguish between variability and uncertainty $[2,55]$ by running second order Monte Carlo simulations [56-58]. In such a case, the efficiency of different risk reduction measures, in absolute or relative terms, is estimated with a confidence interval capturing the uncertainty.

Nevertheless, for the time being, these promising statistical and probabilistic techniques have not yet been fully exploited in the MRA arena. They could be furthermore used in both exposure assessment and hazard characterization to ultimately quantify probability of exposure and probability of illness (Figure 1). Moreover, integration of variability and uncertainty along the farm-to-human continuum, with or without the help of omic technology, could render the risk assessment too complex and then difficult (not to say impossible) to use by risk managers at the operational level. As recently stated, "Assessment needs inclusion of variability and uncertainty, management needs discrete decisions" [59]. An effort in communication has to be made, as well as an effort in developing easy-to-use decision support tools. Some are now in development [60], others are already on the market [61] and used by food safety authorities [62,63].

\section{Foodborne pathogen risk assessment as a part of a global challenge in food safety}

Food safety is not limited to pathogenic microorganisms: chemical risk needs to be assessed as well. On top of this, nutrition component of food is also important. Consumer can be lost among numerous, and somewhat contradictory, pieces of information concerning food and diet spread by media and internet, there is a need for balanced, scientifically-based, messages. To address this demand, a risk and benefit assessment (RBA) discipline has emerged recently [64"]. The EFSA authority [65] advises mirroring the traditional risk analysis process to undertake a risk-benefit analysis, while considering some differences like the addition of a benefit assessment and a risk-benefit comparison. When possible, RBA output is expressed in term of burden of diseases, estimated using quantitative metrics such as
Disability Adjusted Life Years (DALY). These metrics provide a comprehensive assessment of the consequences of a disease by integrating the quality of life lost and premature death [66]. The first and most popular studies related to RBA concerned a comparison of chemical risk and nutritional benefit linked to fish consumption [67-69], however, research has now diversified into a wider range of food categories. RBA approach, with DALY as endpoint, is integrated in the FDA tool "iRISK" [62].

Beyond health criteria, economic and environmental criteria may be also important for consumers, manufacturers and authorities. Multi-Decision Criteria Analysis (MCDA) [70] is a valuable technique to address this multidimensional issue [ $\left[71^{\circ}\right]$. It explicitly and systematically combines a large range of quantitative and qualitative factors. MCDA has been recently used to rank biological hazards [72] and evaluate chemicals based on their exposure potential [73]. MCDA and more generally risk ranking methodologies might provide, in the future, additional insights to deliver eventually a comprehensive, well-structured, analysis on which risk managers could lean on to make decisions and communicate them adequately.

\section{Conclusion}

In recent years, there has been a strong tendency in providing food safety decisions based upon quantitative risk assessment. Variability and uncertainty inherent to biological processes are now considered in the assessment through the use of probabilistic techniques. The current trend is to separate uncertainty from variability, when building models and communicating results, and, to use Bayesian approaches in the data analysis process. There are also attempts to include omics in microbial risk assessment. That will open new perspective, particularly in hazard identification: potential new microbiological hazards might be detected at an early stage. Omic technologies could also help in understanding and then characterizing variability of microorganisms and their responses to stress encountered in the farm-to-fork-tohuman continuum. Finally, it seems reasonable to forecast that risk-benefit assessment including microbiological, chemical and nutritional issues, will take off in the next ten years as well as more comprehensive assessment including economical and sustainability considerations.

\section{References and recommended reading}

Papers of particular interest, published within the period of review, have been highlighted as:

- of special interest

• of outstanding interest

1. Codex Alimentarius Commission: Principles and guidelines for the conduct of a microbiological risk assessment. CAC/GL-30. Joint FAO/WHO Food Standards Programme; 1999.

2. Cummins E: Quantifying microbial propagation. In Modeling in Food Microbiology. From Predictive Microbiology to Exposure Assessment. Edited by Membré J-MM., Valdramidis V. ISTE Press Ltd and Elsevier Ltd; 2016:17-31. 
3. Stasiewicz MJ, den Bakker HC, Wiedmann M: Genomics tools in -. microbial food safety. Curr Opin Food Sci 2015, 4:105-110. Comprehensive review on genomic tools used for food safety. Focus on WGS methods dedicated to hazard identification and outbreak surveillance and comparison with other typing methods.

4. Xu Y-J, Wu X: Foodomics in microbiological investigations. Curr Opin Food Sci 2015, 4:51-55.

5. FAO/WHO: Principles and guidelines for incorporating microbiological risk assessment in the development of food safety standards, guidelines and related texts. Report of a Joint FAO/WHO Consultation; Kiel, Germany, 18-22 March 2002: 2002.

6. Lamboni M, Sanaa M, Tenenhaus-Aziza F: Sensitivity analysis for critical control points determination and uncertainty analysis to link fso and process criteria: application to Listeria monocytogenes in soft cheese made from pasteurized milk. Risk Anal 2014, 34:751-764.

7. Membré J-M: Hazard appraisal (HACCP) - establishment of performance criteria. In Encyclopedia of Food Microbiology, 2nd ed.. Edited by Batt C, Tortorello M-L.Elsevier; 2014.

8. Nauta M, Andersen JK, Tuominen P, Ranta J, Lindqvist R: Riskbased microbiological criteria for Campylobacter in broiler meat: a comparison of two approaches. Food Control 2015 , 53:177-184

9. van Schothorst M, Zwietering MH, Ross T, Buchanan RL, Cole MB: Relating microbiological criteria to food safety objectives and performance objectives. Food Control 2009, 20:967-979.

10. Zwietering MH, Gorris LGM, Farber JM: Operationalising a performance objective with a microbiological criterion using a risk-based approach. Food Control 2014.

11. Nauta MJ: A Modular Process Risk Model Structure for Quantitative Microbiological Risk Assessment and its Application in an Exposure Assessment of Bacillus cereus in REPFED. 2001:. Available at http://www.rivm.nl/bibliotheek/rapporten/149106007.html.

12. Bouwknegt M, Verhaelen K, Rzezutka A, Kozyra I, Maunula L, von Bonsdorff CH, Vantarakis A, Kokkinos P, Petrovic T, Lazic S et al.: Quantitative farm-to-fork risk assessment model for norovirus and hepatitis $A$ virus in European leafy green vegetable and berry fruit supply chains. Int J Food Microbiol 2015, 198:50-58.

13. Polo D, Feal X, Romalde JL: Mathematical model for viral depuration kinetics in shellfish: an useful tool to estimate the risk for the consumers. Food Microbiol 2015, 49:220-225.

14. Stals A, Jacxsens $L$, Baert $L$, Van Coillie E, Uyttendaele M: A quantitative exposure model simulating human norovirus transmission during preparation of deli sandwiches. Int J Food Microbiol 2015, 196:126-136.

15. Daelman J, Membré J-M, Jacxsens L, Vermeulen A, Devlieghere F, Uyttendaele M: A quantitative microbiological exposure assessment model for Bacillus cereus in REPFEDs. Int $J$ Food Microbiol 2013, 166:433-449.

16. Sneed J, Phebus R, Duncan-Goldsmith D, Milke D, Sauer K, Roberts KR, Johnson D: Consumer food handling practices lead to cross-contamination. Food Prot Trends 2015, 35:36-48.

17. Røssvoll E, Sørheim O, Heir E, Møretrø T, Olsen NV, Langsrud S: Consumer preferences, internal color and reduction of shigatoxigenic Escherichia coli in cooked hamburgers. Meat Sci 2014, 96:695-703.

18. Haas CN, Rose JB, Gerba CP: Quantitative Microbial Risk Assessment. John Wiley \& Sons, Inc.; 2014.

19. Aryani DC, den Besten HMW, Hazeleger WC, Zwietering MH: Quantifying variability on thermal resistance of Listeria monocytogenes. Int J Food Microbiol 2015, 193:130-138.

20. Lianou A, Koutsoumanis KP: Strain variability of the behavior of foodborne bacterial pathogens: a review. Int J Food Microbiol 2013, 167:310-321.

21. Aspridou Z, Koutsoumanis KP: Individual cell heterogeneity as

- variability source in population dynamics of microbial inactivation. Food Microbiol 2015, 45:216-221.

This study demonstrated the individual cell heterogeneity of Salmonella enterica submitted to acidic inactivation treatment.
22. Brul S, Bassett J, Cook P, Kathariou S, McClure P, Jasti PR, Betts R: 'Omics' technologies in quantitative microbial risk assessment. Trends Food Sci Technol 2012, 27:12-24.

23. Underwood AP, Dallman T, Thomson NR, Williams M, Harker K Perry N, Adak B, Willshaw G, Cheasty T, Green J et al.: Public health value of next-generation DNA sequencing of enterohemorrhagic Escherichia coli isolates from an outbreak. J Clin Microbiol 2013, 51:232-237.

24. Pielaat A, Boer MP, Wijnands LM, van Hoek AHAM, Bouw E,

- $\quad$ Barker GC, Teunis PFM, Aarts HJM, Franz E: First step in using molecular data for microbial food safety risk assessment; hazard identification of Escherichia coli O157:H7 by coupling genomic data with in vitro adherence to human epithelial cells. Int J Food Microbiol 2015, 213:130-138.

This study illustrates how omic technology could bring an added value to risk assessment.

25. Mather AE: There's no place like home. Nat Rev Microbiol 2015, 13:331.

26. Leonard SR, Mammel MK, Lacher DW, Elkins CA: Application of metagenomic sequencing to food safety: detection of Shiga toxin-producing Escherichia coli on fresh bagged spinach. Appl Environ Microbiol 2015.

27. Martinez JL, Coque TM, Baquero F: What is a resistance gene? Ranking risk in resistomes. Nat Rev Microbiol 2015, 13:116-123.

28. Herrero M, Simo C, Garcia-Canas V, Ibanez E, Cifuentes A: Foodomics: MS-based strategies in modern food science and nutrition. Mass Spectrom Rev 2012, 31:49-69.

29. Sandrin TR, Goldstein JE, Schumaker S: MALDI TOF: MS profiling of bacteria at the strain level: a review. Mass Spectrom Rev 2013, 32:188-217.

30. Bhagwat AA, Bhagwat M: Methods and tools for comparative genomics of foodborne pathogens. Foodborne Pathog Dis 2008, 5:487-497.

31. Mataragas M, Rovetto F, Bellio A, Alessandria V, Rantsiou K, Decastelli L, Cocolin L: Differential gene expression profiling of Listeria monocytogenes in Cacciatore and Felino salami to reveal potential stress resistance biomarkers. Food Microbiol 2015, 46:408-417.

32. Desriac N, Coroller L, Jannic F, Postollec F, Sohier D: mRNA biomarkers selection based on partial least square algorithm in order to further predict Bacillus weihenstephanensis acid resistance. Food Microbiol 2015, 45:111-118.

33. den Besten HMW, Arvind A, Gaballo HMS, Moezelaar R, Zwietering MH, Abee T: Short- and long-term biomarkers for bacterial robustness: a framework for quantifying correlations between cellular indicators and adaptive behavior. PLOS One 2010:5.

34. den Besten HMW, Effraimidou S, Abee T: Catalase activity as a biomarker for mild-stress-induced robustness in Bacillus weihenstephanensis. Appl Environ Microbiol 2013, 79:57-62.

35. Cossart P: Illuminating the landscape of host-pathogen interactions with the bacterium Listeria monocytogenes. Proc Natl Acad Sci USA 2011, 108:19484-19491.

36. Wurtzel O, Sesto N, Mellin JR, Karunker I, Edelheit S, Becavin C, Archambaud C, Cossart P, Sorek R: Comparative transcriptomics of pathogenic and non-pathogenic Listeria species. Mol Syst Biol 2012, 8:583.

37. Tang S, Orsi R, den Bakker H, Wiedmann M, Boor K, Bergholz T: Transcriptomic analysis of the adaptation of Listeria monocytogenes to growth on vacuum-packed cold smoked salmon. Appl Environ Microbiol 2015, 81:6812-6824.

38. Alvarez-Ordóñez A, Broussolle V, Colin P, Nguyen-The C, Prieto M: The adaptive response of bacterial food-borne pathogens in the environment, host and food: implications for food safety. Int J Food Microbiol 2015, 213:99-109.

39. Yang R, Du Z, Han Y, Zhou L, Song Y, Zhou D, Cui Y: Omics strategies for revealing Yersinia pestis virulence. Front Cell Infect Microbiol 2012, 2:157. 
40. Gale P, Hill A, Kelly L, Bassett J, McClure P, Le Marc Y, Soumpasis I: Applications of omics approaches to the development of microbiological risk assessment using RNA virus dose-response models as a case study. J Appl Microbiol 2014, 117:1537-1548.

41. de Lorenzo V: Pseudomonas aeruginosa: the making of a pathogen. Environ Microbiol 2015, 17:1-3.

42. Yoon SH, Han M-J, Jeong H, Lee CH, Xia X-X, Lee D-H, Shim JH, Lee SY, Oh TK, Kim JF: Comparative multi-omics systems analysis of Escherichia coli strains B and K-12. Genome Biol 2012, 13:R37.

43. Vignes M, Vandel J, Allouche D, Ramadan-Alban N, CiercoAyrolles C, Schiex T, Mangin B, de Givry S: Gene regulatory network reconstruction using Bayesian networks, the Dantzig selector, the Lasso and their meta-analysis. PLoS One 2011, 6 http://dx.doi.org/10.1371/journal.pone.0029165.

44. Hanisch D, Zien A, Zimmer R, Lengauer T: Co-clustering of biological networks and gene expression data. Bioinformatics 2002, 18:S145-S154.

45. Pin C, Rolfe M, Munoz-Cuevas M, Hinton J, Peck M, Walton N, Baranyi $\mathrm{J}$ : Network analysis of the transcriptional pattern of young and old cells of Escherichia coli during lag phase. BMC Syst Biol 2009, 3:108.

46. Shafiei M, Dunn KA, Boon E, MacDonald SM, Walsh DA, Gu H, Bielawski JP: BioMiCo: a supervised Bayesian model for inference of microbial community structure. Microbiome 2015 http://dx.doi.org/10.1186/s40168-015-0073-x.

47. Greiner M, Smid J, Havelaar AH, Müller-Graf C: Graphical models and Bayesian domains in risk modelling: application in microbiological risk assessment. Prev Vet Med 2013, 110:4-11.

48. Beaudequin D, Harden F, Roiko A, Stratton H, Lemckert C,

- Mengersen K: Beyond QMRA modelling microbial health risk as a complex system using Bayesian networks. Environ Int 2015, 80:8-18.

Comprehensive review on use of Bayesian networks in quantitative microbiological risk assessment.

49. Perez-Rodriguez F, Gonzalez-Garcia P Valero A, Hernandez M, Rodriguez-Lazaro D: Impact of the prevalence of different pathogens on the performance of sampling plans in lettuce products. Int J Food Microbiol 2014, 184:69-73.

50. Busschaert $\mathrm{P}$, Geeraerd $\mathrm{AH}$, Uyttendaele M, Van Impe JF: Hierarchical Bayesian analysis of censored microbiological contamination data for use in risk assessment and mitigation. Food Microbiol 2011, 28:712-719.

51. Jaloustre S, Cornu M, Morelli E, Noël V, Delignette-Muller ML: Bayesian modeling of Clostridium perfringens growth in beefin-sauce products. Food Microbiol 2011, 28:311-320.

52. Diao MM, André S, Membré J-M: Meta-analysis of D-values of proteolytic Clostridium botulinum and its surrogate strain Clostridium sporogenes PA 3679. Int J Food Microbiol 2014, 174:23-30.

53. Rigaux C, Ancelet S, Carlin F, Nguyen-thé C, Albert I: Inferring an augmented Bayesian network to confront a complex quantitative microbial risk assessment model with durability studies: application to Bacillus cereus on a courgette purée production chain. Risk Anal 2013, 33:877-892.

54. Barker GC, Malakar PK, Del Torre M, Stecchini ML, Peck MW: Probabilistic representation of the exposure of consumers to Clostridium botulinum neurotoxin in a minimally processed potato product. Int J Food Microbiol 2005, 100:345-357.

55. Glass K, Ford L, Kirk MD: Drivers of uncertainty in estimates of foodborne gastroenteritis incidence. Foodborne Pathog Dis 2014, 11:938-944

56. Smid J, de Jonge R, Havelaar AH, Pielaat A: Variability and uncertainty analysis of the cross-contamination ratios of Salmonella during pork cutting. Risk Anal 2013, 33:1100-1115.

57. Pujol L, Albert I, Magras C, Johnson NB, Membré J-M: Estimation and evaluation of management options to control and/or reduce the risk of not complying with commercial sterility. Int J Food Microbiol 2015, 213:124-129.

58. Cummins E, Nally P, Butler F, Duffy G, O'Brien S: Development and validation of a probabilistic second-order exposure assessment model for Escherichia coli 0157:H7

contamination of beef trimmings from Irish meat plants. Meat Sci 2008, 79:139-154

59. Zwietering $\mathrm{MH}$ : Risk assessment and risk management for safe foods: assessment needs inclusion of variability and uncertainty, management needs discrete decisions. Int J Food Microbiol 2015, 213:118-123.

60. Mataragas M, Alessandria V, Rantsiou K, Cocolin L: Evaluation of the Listeria monocytogenes inactivation during post-process storage of fermented sausages: a basis for the development of a decision support tool. Food Control 2015, 50:568-573.

61. Tenenhaus-Aziza F, Ellouze M: Software for predictive microbiology and risk assessment: a description and comparison of tools presented at the ICPMF8 Software Fair Food Microbiol 2015, 45:290-299.

62. Chen YH, Dennis SB, Hartnett E, Paoli G, Pouillot R, Ruthman T, Wilson M: FDA-iRISK - a comparative risk assessment system for evaluating and ranking food-hazard pairs: case studies on microbial hazards. J Food Prot 2013, 76:376-385.

63. EFSA: Scientific opinion on the development of a risk ranking toolbox for the EFSA BIOHAZ Panel. EFSA J 2015, 13:131.

64. Boué G, Guillou S, Antignac J-P, Le Bizec B, Membré J-M: Public

- $\quad$ health risk-benefit assessment associated with food consumption - a review. Eur J Nutr Food Safety 2015, 5:32-58

Comprehensive revue on risk and benefit assessment, with a detailed presentation of methodologies (including DALY metric) to make comparison between food consumption scenarios. The main applications to date are presented.

65. EFSA: Guidance on human health risk-benefit assessment of foods. Scientific opinion. EFSA J 2010, 8:1-40.

66. Gold MR, Stevenson D, Fryback DG: HALYs and QALYs and DALYs, Oh My: similarities and differences in summary measures of population health. Annu Rev Public Health 2002 , 23:115-134.

67. FAO/WHO: Joint FAO/WHO Expert Consultation on the Risks and Benefits of Fish Consumption. 2010.

68. EFSA: Opinion of the Scientific Panel on contaminants in the food chain on a request from the European Parliament related to the safety assessment of wild and farmed fish (Question N EFSA-Q-2004-22, Adopted on 22 June 2005). EFSA J 2005, 236:1-118.

69. VKM: Fish and Seafood Consumption in Norway-Benefits and Risks. Norwegian Scientific Committee for Food Safety, March 2006. English Summary. 2006.

70. Montibeller G, Franco A: Multi-criteria decision analysis for strategic decision making. Handbook of Multicriteria Analysis Applied Optimization. Springer; 2010:: 25-48.

71. van der Fels-Klerx HJ, Asselt EDv, Raley M, Poulsen M,

- Korsgaard H, Bredsdorff L, Nauta M, Flari V, D'Agostino M, Coles DG et al.: Critical review of methodology and application of risk ranking for prioritisation of food and feed related issues, on the basis of the size of anticipated health impact. EFSA Supporting Publication 2015, EN-710:106.

A report presenting the methods and tools which could, in a near future, enable to embed microbial issues into a more comprehensive assessment including chemistry, nutrition but also cost and sustainability.

72. Ruzante JM, Davidson VJ, Caswell J, Fazil A, Cranfield JAL, Henson SJ, Anders SM, Schmidt C, Farber JM: A multifactorial risk prioritization framework for foodborne pathogens. Risk Anal 2010, 30:724-742

73. Mitchell J, Pabon N, Collier ZA, Egeghy PP, Cohen-Hubal E, Linkov I, Vallero DA: A decision analytic approach to exposurebased chemical prioritization. PLOS ONE 2013, 8:e70911. 